\title{
Emplacement Temperatures of Pyroclastic and Volcaniclastic Deposits in Kimberlite Pipes in SouthernAfrica
}

\author{
G. Fontana (1,2), C. Mac Niocaill (1), R.J. Brown (2), R.S.J. Sparks (2), and M. Field(1) \\ (1) Department of Earth Sciences, University of Oxford, Parks Road, Oxford OX1 3PR, UK \\ (2) Department of Earth Sciences, Wills Memorial Building, University of Bristol, Queen's \\ Road, Bristol, BS7 1RJ, UK
}

The estimation of the emplacement temperatures of pyroclastic deposits, using palaeomagnetic techniques pioneered by Aramaki and Arimoto (1957), has been successfully carried out on many deposits worldwide. Several attempts have been made to estimate the emplacement temperatures of kimberlite deposits. The general absence of thermal metamorphic effects on entrained xenoliths and in adjacent country rock led some authors to propose emplacement temperatures of $<500^{\circ} \mathrm{C}$ for volcaniclastic kimberlite deposits (e.g. Watson, 1967; Mitchell, 1986; Skinner and Marsh, 2004). Sosman (1938) deduced intrusion temperatures of $340^{\circ} \mathrm{C}$ for North American kimberlites from thermal effects of coal inclusions (see Watson, 1967). Stasiuk et al. (1999) interpreted reflectance values in dispersed organic matter inclusions within Canadian kimberlites to deduce temperatures of $150-200^{\circ} \mathrm{C}$ for pipe-facies and $<100^{\circ} \mathrm{C}$ for crater-facies volcaniclastic kimberlites. Palaeomagnetic studies by McFadden (1977) on wall rock samples and accidental inclusions pipes suggested emplacement temperatures of $\sim 300^{\circ} \mathrm{C}$. Stability fields of alteration assemblages in kimberlite pyroclastic rocks give minimum temperatures of $300-340^{\circ} \mathrm{C}$ (Stripp et al., 2006).

Here we present the results of palaeomagnetic measurements of the emplacement temperatures of pyroclastic and volcaniclastic kimberlite deposits within three contrasting kimberlite pipes in southern Africa (Orapa $\mathrm{A} / \mathrm{K} 1$, Venetia $\mathrm{K} 1$ and $\mathrm{K} 2$ ) for which the internal geology is well constrained by recent geological studies. We discuss the implications of the results in the context of the supporting geological evidence for the mode of formation of the kimberlite deposits and for the nature of kimberlite eruptions.

\section{Sampling strategy}

Eight tholeiitic Stormberg Formation basalt lithic clasts were sampled from the Orapa north pipe (NPK - pyroclastic kimberlite) and south pipe (SVK - volcaniclastic kimberlite and basalt talus breccias). Eleven individual specimen cores were demagnetized from the eight sampled clasts. Thirty-five samples were collected from the $\mathrm{K} 1$ and $\mathrm{K} 2$ pipes, Venetia mine. Thirty-three samples, mainly of amphibolite, were collected from the two main lithofacies in $\mathrm{K} 2$ (matrix-supported volcaniclastic kimberlite breccias $(\mathrm{mVKBr})$ massive volcaniclastic kimberlite deposits (MVK). Two samples were collected from MVK deposits in K1.

\section{Results - Orapa}

The eight samples are strongly magnetic displaying NRM (natural remanent magnetism) intensities ranging from 0.69 to 26.10 amperes/meter $(\mathrm{A} / \mathrm{m})$. The intensities of north pipe (NPK) samples ( 14.5 to 26.0 $\mathrm{A} / \mathrm{m})$ are one or two orders of magnitude greater than samples from the south pipe $(\sim$ 0.69 to $6.0 \mathrm{~A} / \mathrm{m})$. Following demagnetization to a peak temperature of $590^{\circ} \mathrm{C}$, five of the eight samples were demagnetized to less than $5 \%$ of the original NRM intensity; the remaining three samples (from the north pipe) retain intensities between 12 and $27 \%$. These samples have not been remagnetized by the heating process which indicates the samples contain ferromagnetic grains with $\mathrm{T}_{b} \mathrm{~S}>590^{\circ} \mathrm{C}$ (e.g. haematite or titanohaematite grains; $\mathrm{T}_{\mathrm{c}}$ of $680^{\circ} \mathrm{C}$ ). Homogeneous thermal demagnetization behaviour is displayed between samples taken from the same clast. During thermal demagnetization, a low- 
unblocking temperature $\left(\mathrm{T}_{\mathrm{ub}}\right)$ component was removed in 5 cores by heating to 100 or $140^{\circ} \mathrm{C}$. These components possessed no directional grouping and are interpreted as being a low-stability VRM (viscous remnanent magnetism) component acquired during storage of the samples. After removal of these VRM components, all samples displayed well-defined characteristic (chRM) single or two-component magnetizations.

Figure 1 displays $T_{e}$ (emplacement temperatures) estimates determined from individual lithic clasts, using methods described above. All four NPK clasts provide minimum $T_{e}$ estimates, interpreted as being emplaced $>590^{\circ} \mathrm{C}$. Maximum $\mathrm{T}_{\mathrm{e}}$ estimates of $140^{\circ} \mathrm{C}$ are provided by two of the SVK clasts, and the one talus deposit clast. These are interpreted to have been emplaced at ambient temperatures, or $<140^{\circ} \mathrm{C}$, which is the minimum valid $T_{e}$ estimate after removal of low-stability VRM components. A $\mathrm{T}_{\mathrm{e}}$ estimate of $340-380^{\circ} \mathrm{C}$ is provided by the one SVK sample displaying a two-component magnetization.

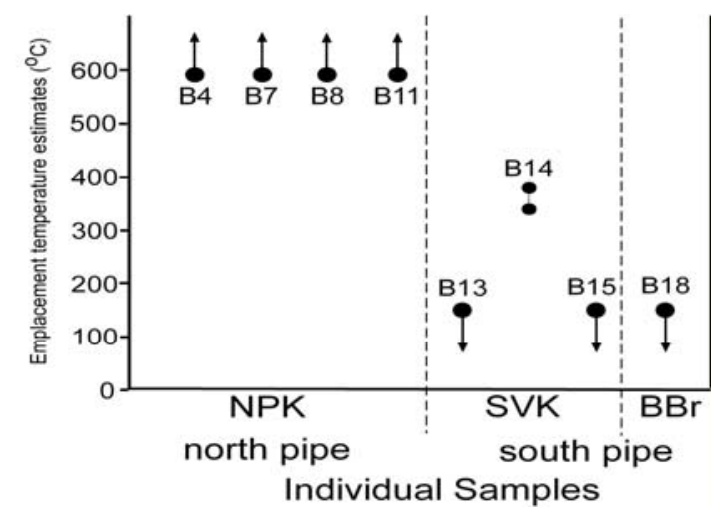

Figure 1. Emplacement temperatures for lithofacies in Orapa $\mathrm{A} / \mathrm{K} 1$ pipe.

The results from NPK samples $\left(\mathrm{T}_{\mathrm{e}}>590^{\circ} \mathrm{C}\right)$ implies that NPK is a primary pyroclastic deposit emplaced at significantly elevated temperatures, as proposed by Field at al. (1997) based on field and petrographic evidence. $\mathrm{T}_{\mathrm{e}}$ estimates for $\mathrm{SVK}$ samples of $<140^{\circ} \mathrm{C}$ and $340-380^{\circ} \mathrm{C}$ implies that clasts were emplaced in SVK at both ambient and elevated temperatures. This indicates both epiclastic and pyroclastic depositional processes occured in the south pipe. The result from talus deposits of $<140^{\circ} \mathrm{C}$ is consistent with emplacement by epiclastic processes.

\section{Results - Venetia}

Using data from dolerite clasts, upper bounds on $\mathrm{T}_{\mathrm{e}}$ for $\mathrm{VKBr}$ deposits is placed at 460 $500^{\circ} \mathrm{C}$ (depicted by the upper horizontal dashed line, Figure 2).

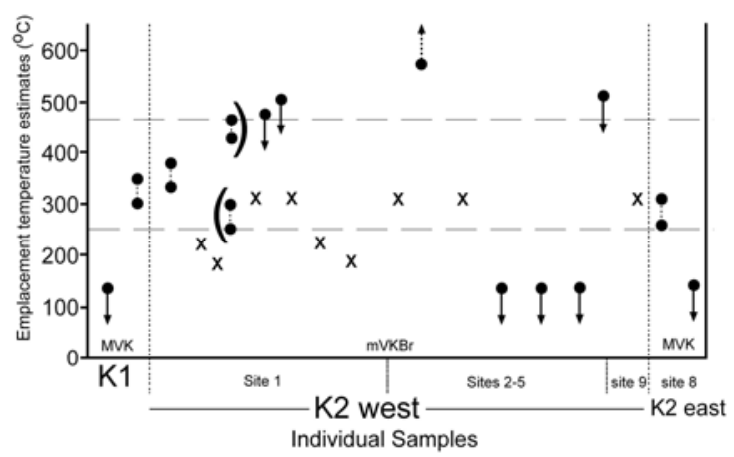

Figure 2. Emplacement temperatures for pyroclastic deposits in Venetia $\mathrm{K} 1$ and $\mathrm{K} 2$ pipes.

These clasts were exclusive to site 1 (Fig. 1B) and are unlikely to be wholly representative of $\mathrm{K} 2 \mathrm{VKBr}$ deposits. Two samples obtained from a single lithic clast in $\mathrm{mVKBr}$ deposits at site 1 give conflicting $\mathrm{T}_{\mathrm{e}}$ estimates of 260$300^{\circ} \mathrm{C}$ and $420-460^{\circ} \mathrm{C}$ (parentheses in Fig. 1). This is more likely to be representative of magnetic inhomogeneity within the clast (i.e. alteration), rather than any indication of a thermal gradient developed within the clast. The evidence of VRM overprinting in some clasts implies $\mathrm{T}_{\mathrm{e}}$ estimates below $260^{\circ} \mathrm{C}$ are unlikely to be valid, which is indicated by the lower dashed horizontal line. Scatter in the $T_{e}$ estimates is most likely a result of variable amounts of CRM (chemical remanent magnetism) or VRM overprinting which has occurred since emplacement, and to some extent actual variation in the $T_{e}$ of individual clasts.

\section{Implications}

Thermoremanent magnetism studies of lithic inclusions have successfully differentiated the emplacement temperatures of a variety of volcaniclastic lithofacies preserved within the Orapa and Venetia kimberlite pipes (Fig. 3). Obtained $\mathrm{T}_{\text {dep }}$ values are consistent with the field evidence of the various deposits. $\mathrm{T}_{\mathrm{dep}}$ 
estimates for pyroclastic deposits are consistent with previous estimates of kimberlite emplacement temperatures $\left(\leq 340^{\circ} \mathrm{C}\right.$; see Sosman 1938; Watson 1967; McFadden, 1977; Stasiuk et al., 1999).

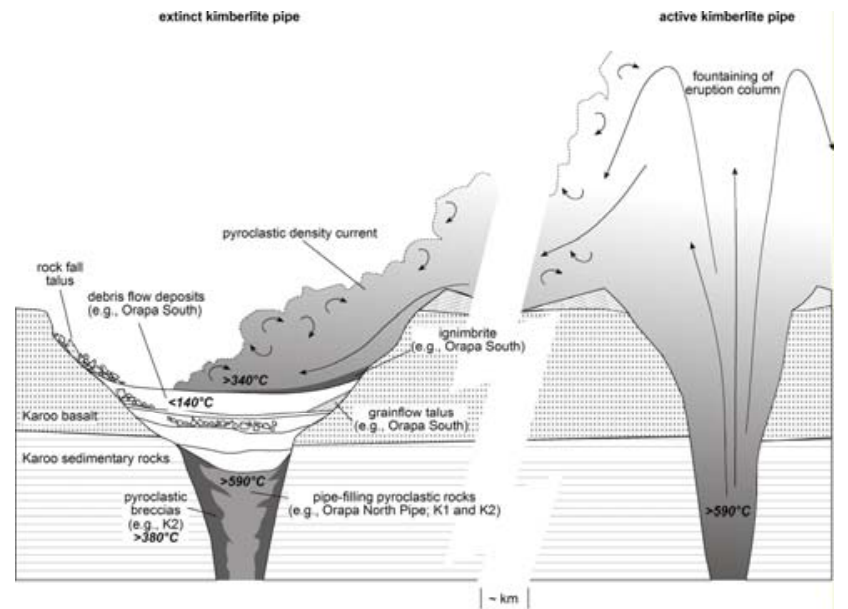

Figure 3. Cartoon illustrating emplacement temperatures for various pyroclastic and epiclastic lithofacies in southern African kimberlite pipes.

The $\mathrm{T}_{\text {dep }}$ values obtained for pipe-filling pyroclastic deposits $\left(260-300^{\circ} \mathrm{C}->590^{\circ} \mathrm{C}\right)$ are similar to the emplacement temperatures of extrusive pyroclastic rocks erupted from more silicic volcanic systems Pyroclastic deposits can become welded at the upper end of this temperature range and this is particularly common in pyroclastic deposits of low-viscosity magmas (Sumner 1998). Welding textures have recently been recognised in some rocks in Venetia $\mathrm{K} 2$ pipe (Brown et al., in press, a, b). Low $\mathrm{T}_{\text {dep }}$ estimates for clasts in the SVK and talus breccias $\left(<140^{\circ} \mathrm{C}\right)$, which show a singlecomponent magnetization, are consistent with emplacement at ambient temperatures by epiclastic processes (rock fall and debris flow).

\section{References}

Aramaki, S., Akimoto, S., 1957. Temperature estimate of pyroclastic deposits by natural remanent magnetism. American Journal of Science 255, 619627.

Brown, R.J., Tait, M., Field, M., Sparks R.S.J., in press. Geology of a complex kimberlite pipe (Venetia K2 pipe, South Africa): insights into conduit processes during explosive ultrabasic eruptions. Bulletin of Volcanology. doi: 10.1007/s00445-008-0211-4. the welding of pyroclasts from very low viscosity magmas: evidence from kimberlite volcanoes. Journal of Geology.

Field, M., Gibson, J.G. Wilkes, T.A. Gababotse, J., Knutjwe P., 1997. The geology of the Orapa A/K1 kimberlite Botswana: Further insight into the emplacement of kimberlite pipes. Russian Geology and Geophysics 38, 24-39.

McFadden, P.L. 1977. A palaeomagnetic determination of the emplacement temperature of some South African kimberlites. Geophysics Journal of the Royal Astronomical Society 50, 605-619.

Mitchell, R.H., 1986. Kimberlites: Mineralogy, Geochemistry, and Petrology. Plenum Press, New York 442 pp.

Skinner, E.M.W., Marsh, J.S., 2004. Distinct kimberlite pipe classes with contrasting eruption processes. Lithos 76, 183-200.

Sosman, R.B., 1938. Evidence on the intrusiontemperature of peridotites. American Journal of Science 35, 353-359.

Stasiuk, L.D., Lockhart, G.D., Nassichuk, W.W., Carlson J.A., 1999. Thermal maturity evaluation of dispersed organic matter inclusions from kimberlite pipes, Lac de Gras, Northwest Territories, Canada. International Journal of Coal Geology 40, 1-25.

Stripp G.R., Field, M., Schumacher, J.C., and Sparks, R.S.J., 2006. Post-emplacement serpentinization and related hydrothermal metamorphism in a kimberlite from Venetia, South Africa. Journal of Metamorphic Geology 24, 515-534.

Watson, K.D., 1967. Kimberlites of Eastern North America. In: Wyllie, P. J. (ed), Ultramafic and Related Rocks. John Wiley \& Sons, Inc, New York 312-323. 